\title{
ANÁLISE DO LIVRO I DO NOVO CÓDIGO DE PROCESSO CIVIL: UM REFLEXO DO FENÔMENO DA CONSTITUCIONALIZAÇÃO DO PROCESSO CIVIL
}

\section{ANALISYS OF BOOK I OF THE NEW CODE OF CIVIL PROCEDURE: A REFLEX OF THE PHENOMENON OF CONSTITUCIONALIZATION OF CIVIL PROCEDURE}

\author{
Yvete Flavio da Costa $^{1}$ \\ Deborah Aline Antonucci Moretti ${ }^{2}$
}

\section{RESUMO}

O presente artigo tem por objetivo analisar o Livro I do Novo Código de Processo Civil, denominado Das normas processuais civis interligando-o com o processo de constitucionalização que o processo civil vem passando após a promulgação da Constituição Federal de 1988. Isso porque, a partir da promulgação da Constituição Democrática, esta passou a ser vetor máximo de todo o sistema jurídico. Ou seja, todo o ordenamento deve estar em conformidade com seus princípios e regras, sob pena de ser considerado inconstitucional. O Código anterior, promulgado em 1973, antes, portanto, da Constituição atual, não tinha essa preocupação, pois naquele momento, o vetor máximo do ordenamento jurídico era o Código Civil de 1916. Por isso, em seu texto, não eram encontrados, na forma expressa, alguns dos postulados fundamentais ao desenvolvimento válido e regular do processo civil, tais como o contraditório, a ampla defesa e a publicidade processual. Com isso em mente, o legislador trouxe, nesse capítulo, uma espécie de apanhado de normas de introdução ao processo civil, regulando a aplicação do processo no tempo e no espaço, além de positivar os ditames constitucionais que não se encontravam presentes de forma expressa no texto codificado anterior. Justifica-se então, a presente pesquisa, na necessidade de efetuar um aprofundamento no estudo da constitucionalização do processo civil, tendo em vista a contemporaneidade do assunto.

De forma a possibilitar o aprofundamento temático do assunto, foram empregados os métodos lógico dedutivo e lógico indutivo, já que a pesquisa teve por base a investigação dedutiva da nova legislação.

Palavras-chave: Novo código de processo civil, Constitucionalização, Vetor máximo

\begin{abstract}
This article aims to analyze the Book I of the New Code of Civil Procedure, called "The civil procedural rules" linking it to the constitutionalization process that civil process has going by after the enactment of the 1988 Federal Constitution. This is because, since its enactment, the Democratic Constitution became maximum vector of the entire legal system, so that all laws must comply with its principles and rules, under penalty of being considered unconstitutional. The previous Code, enacted in 1973, before the current Constitution, had no such concern because at that time, the maximum vector law was the Civil Code of 1916. So in that text, there was not some of the fundamental assumptions for valid and regular

\footnotetext{
1 Doutorada em Direito pela Pontifícia Universidade Católica de São Paulo - PUC/SP, São Paulo, (Brasil). Professora pela Universidade Estadual Paulista -"Júlio de Mesquita Filho" - UNESP, São Paulo, (Brasil). E-mail: yvetecosta@gmail.com

${ }^{2}$ Mestranda pela Universidade Estadual Paulista -"Júlio de Mesquita Filho" - UNESP, São Paulo, (Brasil). E-mail: deborahmoretti@gmail.com
} 
development of civil procedure, such as contradictory. With that in mind, the legislator brought in this chapter, a kind of law of introduction to civil procedure rules, regulating the application of the process in time and space, and also brings the constitutional principles that were not explicitly present in the encoded text before.. The present article is justified by the need to carry out a deeper study of the constitution of civil procedure, with a view to the subject nowadays. In order to enable the thematic deepening of the subject, it was employed the logical deductive and inductive methods logical, since the research was based on deductive research of new legislation.

Keywords: New code of civil procedure, Constitutionalization, Maximum vector 


\section{INTRODUÇÃO}

O Novo Código de Processo Civil (Lei 13.105/2015), após muitos anos de discussões acaloradas pelas Comissões Responsáveis por sua elaboração, foi aprovado em 26 de março de 2015, e entrará em vigor em 17 de março de 2016.

Referido diploma legal tem por principal objetivo conferir maior celeridade aos processos judiciais, já que muitos se prolongam por demasiado no tempo, prejudicando o direito da parte do acesso à justiça.

Conforme a exposição de motivos do anteprojeto do Código: O novo Código de Processo Civil tem o potencial de gerar um processo mais célere, mais justo, porque mais rente às necessidades sociais, e muito menos complexo, sendo orientado por cinco objetivos:

1) estabelecer expressa e implicitamente verdadeira sintonia fina com a Constituição Federal;

2) criar condições para que o juiz possa proferir decisão de forma mais rente à realidade fática subjacente à causa; 3) simplificar, resolvendo problemas e reduzindo a complexidade de subsistemas, como, por exemplo, o recursal; 4) dar todo o rendimento possível a cada processo em si mesmo considerado; e, 5) finalmente, sendo talvez este último objetivo parcialmente alcançado pela realização daqueles mencionados antes, imprimir maior grau de organicidade ao sistema, dando-lhe, assim, mais coesão (EXPOSIÇÃO... 2010, p. 14).

Dentre as inúmeras inovações, o presente artigo se pauta em analisar o denominado "Livro I", intitulado "Das normas processuais civis". Este contém dois capítulos, o primeiro denominado "Das normas fundamentais do Processo Civil", que, decorrência prática do movimento de constitucionalização do processo civil, positiva os princípios constitucionais atinentes ao direito processual no novo texto legal.

Apresentando temática inovadora, o capítulo I ainda traz disposições no sentido de introduzir no sistema uma ordem cronológica de conclusão para proferição de sentença ou acórdão, que deve ser respeitada pelos juízes e os tribunais quando do julgamento das demandas lhes trazidas à análise.

Já o capítulo II, denominado "Da aplicação das normas processuais", traz dispositivos no sentido de regular a aplicação da norma processual no tempo e no espaço, além de 
determinar que na ausência de normas que regulem processos eleitorais, trabalhistas ou administrativos, as disposições deste Código lhes serão aplicadas supletiva e subsidiariamente.

Cabe ressaltar que esses preceitos não encontravam equivalentes no Código Buzaid, que não continha uma seção específica que determinasse os princípios do processo civil, trazendo somente, em seu artigo $2^{\circ}$ e 272 , respectivamente, a regra da inércia da jurisdição ${ }^{3}$ e do impulso oficial. ${ }^{4}$

Assim, o presente trabalho tem por objetivo intentar uma análise pontual dos preceitos do Livro I do Novo Diploma Processual, de forma a demonstrar como a inserção desses preceitos pode ser considerada mero reflexo da constitucionalização do Processo Civil.

A Constitucionalização pode ser entendida como o procedimento ao qual foi submetida toda a legislação infraconstitucional a partir da promulgação da Constituição Federal de 1988, que elevou a proteção à dignidade da pessoa humana como valor fundamental a ser perseguido por todo o ordenamento jurídico pátrio, de forma todas as disposições normativas existentes devem ser guiadas por esse parâmetro máximo, não podendo, de forma alguma, contrariá-lo.

Justifica-se então, a presente pesquisa, na necessidade de efetuar um aprofundamento no estudo da constitucionalização do processo civil, tendo em vista a contemporaneidade do assunto, calcado pela recente publicação do texto final do Novo Código de Processo Civil.

A garantia da cientificidade da pesquisa está diretamente relacionada à determinação dos métodos de estudos. Neste ponto, serão expostos os principais métodos e materiais que irão ser utilizados no estudo teórico em voga. Tendo em vista o caráter teórico da pesquisa a realizada, o material preponderantemente utilizado foi o bibliográfico. De forma a possibilitar o aprofundamento temático do assunto, foram empregados os métodos lógico dedutivo e lógico indutivo, já que a pesquisa teve por base a investigação dedutiva da nova legislação.

\footnotetext{
${ }^{3}$ Art. $2^{\circ}$ Nenhum juiz prestará a tutela jurisdicional senão quando a parte ou o interessado a requerer, nos casos e forma legais.

${ }^{4}$ Art. 262. O processo civil começa por iniciativa da parte, mas se desenvolve por impulso oficial.
} 


\section{O ARTIGo $1^{\circ}$ DO NOVO CÓdIGO DE PROCESSO CIVIL E A CONSTITUCIONALIZAÇÃO DO DIREITO PROCESSUAL}

O artigo $1^{\circ}$ do CPC 2015, o qual dispõe que o processo civil será ordenado, disciplinado e interpretado conforme os valores e as normas fundamentais estabelecidos na Constituição da República Federativa do Brasil, observando-se as disposições deste Código, é reflexo direto do denominado "movimento de constitucionalização do processo civil".

Este movimento teve início com a promulgação da Constituição de 1988, chamada por muitos de "Constituição Democrática", já que trouxe a dignidade da pessoa humana como núcleo valorativo principal, que deve ser utilizado como premissa para a interpretação de todos os outros diplomas legislativos, tornando a Constituição um filtro axiológico de todo o ordenamento legislativo pátrio.

A chamada Constituição Cidadã elevou, como princípio fundamental, a dignidade da pessoa humana (art. $1^{\circ}$, III, da $\mathrm{CF} / 88$ ). Trouxe para o início do texto constitucional o capítulo referente aos direitos e garantias fundamentais, originalmente relegado ao seu final. Essa nova ordenação topológica não é ausente de significação. O capítulo foi fortemente influenciado pelos ideais propostos pela Declaração Universal dos Direitos do Homem e tem se denunciado, à evidência na doutrina, a preocupação com a realização dos direitos fundamentais, principalmente os de cunho não patrimonial, ali afirmados. É a busca não só pela declaração, mas pela efetividade e efetivação desses direitos. A ideologia dominante nos ordenamentos constitucionais atuais é justamente esta: não basta indicar um rol de direitos fundamentais é preciso efetivá-los (ZANETI JUNIOR, 2005, p. 251-252).

Não se vive mais a onipotência legalista positivista, tradição em nosso ordenamento jurídico como um todo, bem como assente no direito processual civil. Uma nova reinterpretação sob a ótica constitucional sobre o sistema de ritos cível brasileiro permite observar quão comprometido está o processo civil pátrio com o Estado Democrático com a tutela jurisdicional e com um Poder Judiciário eficiente, sendo este último deveras importante na criação judicial do direito (CRUZ; PIAULINO, 2010, p. 209).

O fenômeno da Constitucionalização pode ser compreendido como o processo de transformação do ordenamento jurídico, que este se torna totalmente impregnado pelas normas 
constitucionais. Um ordenamento jurídico constitucionalizado se caracteriza por uma Constituição extremadamente invasora, capaz de condicionar tanto a legislação como a jurisprudência e o estilo doutrinal, a ação de atores políticos, assim como as relações sociais. (GUASTINI, 2003. p. 49.)

Há de ressaltar que em um primeiro estágio, a constitucionalização do processo dá origem a incorporação de normas processuais na Constituição, caracterizando a base constitucional do direito processual. Num segundo estágio, e sob a égide do Estado Democrático de Direito, a constitucionalização do processo desenvolve-se a partir da implementação dos princípios fundamentais na legislação processual positivada, conforme se deu no caso brasileiro. (COSTA, 2013, p. 60-61)

Assim, a constitucionalização do direito processo civil representa a modificação de parâmetro da hermenêutica tradicional, e significa que a compreensão dos institutos processualistas deve ser realizada conforme a Constituição, já que "o direito processual é fundamentalmente determinado pela Constituição em muitos de seus aspectos e institutos característicos" (GRINOVER; CINTRA; DINAMARCO, 2010, p. 84).

Esse processo se deu em virtude da Constituição ter elevado a princípio fundamental institutos como o devido processo legal, o contraditório e a isonomia, princípios processuais que, se não observados, intentam contra aqueles valores atrelados a dignidade da pessoa humana, ou seja, os direitos fundamentais.

A constitucionalização do direito processual, com a vinculação do tecido normativo infraconstitucional às normas constitucionais, resultou na premissa de que a interpretação da norma infraconstitucional deve ser realizada tendo por base o princípio da supremacia constitucional, ou seja, nenhuma interpretação deve ser desvinculada da valorização da dignidade da pessoa humana, vetor base do ordenamento jurídico brasileiro.

Ocorreu então um movimento de personalização do direito processual, influenciado por aquele com o mesmo nome, do direito civil brasileiro. Na personalização desses institutos, a preocupação central é com a proteção da dignidade da pessoa humana. 
Esta deve ser salvaguardada, oferecendo-se, inclusive, meios de efetivação concreta desses direitos, por meio das garantias, ou seja, dos mecanismos prestacionais de defesa dos direitos fundamentais.

A inclusão do Título "Das normas fundamentais e da aplicação das normas processuais" no Novo CPC é repercussão da incidência direta dos direitos fundamentais nas relações privadas, por meio da eficácia horizontal dos direitos fundamentais. Explica-se. Tradicionalmente, se dizia que os direitos fundamentais, aqueles atinentes a condição humana, deveriam ser observados de forma vertical, ou seja, somente na relação entre Estado e indivíduo. O Estado, amparado pelo princípio da supremacia do interesse público sobre o privado, determinaria a restrição dos direitos do indivíduo em prol dos da coletividade, restringindo, dessa forma, a autonomia de vontade do particular.

No entanto, hoje, prima-se, além da eficácia vertical, também pela eficácia horizontal dos direitos fundamentais, ou seja, é possível a tutela dos direitos fundamentais nas relações entre particulares, nas quais vige o princípio da autonomia da vontade. Nessas situações, em que, dentro de uma relação privada, um direito fundamental restar violado, o juiz deverá usar do método da ponderação para a resolução do conflito de interesses.

Em outras palavras, a eficácia horizontal dos direitos fundamentais determina que a relação privada, mesmo diante da autonomia de vontade, não pode afastar a incidência dos direitos fundamentais, sob pena de ser descaracterizada quando da análise judiciária. Ou seja, os direitos fundamentais não se aplicam somente nas relações verticais, entre a Administração Pública e o administrado, mas vinculam também as relações privadas, devendo ser observados nas relações processuais.

Segundo Humberto Theodoro Júnior, concebe-se, assim, o processo moderno, acima de tudo, como um remédio de justiça, entendida como a convivência social desenvolvida na mais ampla observância dos princípios e garantias observados pela Constituição (THEODORO JUNIOR, 2009, p. 03). Deve haver então uma irradiação objetiva do conteúdo substancial e valorativo das normas constitucionais.

Com isso em mente, o legislador pátrio consubstanciou, no artigo $1^{\circ}$ do novo diploma processual civil a ordenação, disciplina e interpretação conforme os valores e as normas 
fundamentais estabelecidos na Constituição da República Federativa do Brasil, sem, contudo, deixar de observar-se as disposições do Código, confirmando a relação de intimidade entre o processo e a Constituição que a doutrina especializada já preconizava.

Essa preocupação ficou latente na exposição de motivos do anteprojeto do Código de Processo Civil, apresentado na data de 08 de junho de 2010 ao presidente do Senado, José Sarney, pelo presidente da comissão de juristas, ministro Luiz Fux, do Superior Tribunal de Justiça (STJ), já que essa preconiza que a resolução de problemas foi uma das linhas principais de trabalho na elaboração do Anteprojeto de Código de Processo Civil. Deixar de ver o processo como teoria descomprometida de sua natureza fundamental de método de resolução de conflitos, por meio do qual se realizam valores constitucionais. A coerência substancial há de ser vista como objetivo fundamental, todavia, e mantida em termos absolutos, no que tange à Constituição Federal da República. Afinal, é na lei ordinária e em outras normas de escalão inferior que se explicita a promessa de realização dos valores encampados pelos princípios constitucionais (EXPOSIÇÃO... 2010, p. 14).

Assim, em toda sua extensão, o processo se fundiu no programa tutelar idealizado pela ordem jurídica constitucional. Passou, antes de tudo, a ser comandado pelas regras e princípios da Constituição. As normas procedimentais, por sua vez, se viram obrigadas a conviver, no dia a dia do foro, com a supremacia dos direitos e garantias da Lei Maior. E o CPC 2015 confirma essa premissa.

Em síntese, tendo em vista que o processo é uma instituição constitucionalizada, este somente pode ser considerado regular, efetivo e válido quando os ditames constitucionais, a partir do CPC 2015, positivados no texto da codificação, forem concretamente observados.

\section{A INÉRCIA E O IMPULSO OFICIAL}

$\mathrm{O}$ artigo $2^{\circ}$ do Novo Código de Processo Civil, de forma inovadora, traz para o livro inaugural, o disposto no artigo 262 do Código anterior, ao instituir que "O processo começa por iniciativa da parte e se desenvolve por impulso oficial, salvo as exceções previstas em lei." A única diferenciação em relação à norma anterior ${ }^{6}$ se verifica na previsão de exceção, já que, como se sabe, há hipóteses excepcionais em que o magistrado poderá dar início ao 
processo, como por exemplo, no caso de jurisdição voluntária. Por meio desse princípio, uma vez instaurada a relação processual, compete ao juiz mover o procedimento de fase em fase, até esgotar a função jurisdicional (GRINOVER; CINTRA; DINAMARCO, 2010, p. 84).

Ou seja, referido princípio tem por objetivo a assegurar a continuidade dos atos procedimentais e seu avanço em direção aos resultados esperados do processo. Embora a jurisdição seja inerte, o processo, uma vez instaurado, não pode ficar a merce das partes. E é conveniente que assim seja, em virtude do predomínio do interesse público sobre o particular, a exigir que a relação processual, uma vez iniciada, se desenvolva e conclua no tempo mais breve possível (GRINOVER; CINTRA; DINAMARCO, 2010, p. 86).

A partir da conceituação do princípio, percebe-se que ele é fundamental para o desenvolvimento regular e válido da jurisdição, motivo pelo qual foi trazido do anterior título VI para o título único do Livro I da Parte Geral do Novo CPC, que disciplina as normas fundamentais para o processo civil de maneira sistematizada.

\section{INAFASTABILIDADE E RESOLUÇÃO CONSENSUAL DOS CONFLITOS}

$\mathrm{O}$ artigo $3^{\mathrm{o}}$ do novo diploma processual brasileiro vem positivar infraconstitucionalmente a norma prevista no o inciso XXXV do art. 5o da Constituição Federal", instituindo que "não se excluirá da apreciação jurisdicional ameaça ou lesão a direito". A inafastabilidade também pode ser compreendida no sentido da desnecessidade de se buscar soluções administrativas antes de adentrar-se com a demanda no Judiciário. Há exceções a essa premissa: Nas questões desportivas, nos termos do artigo $217, \S 1^{\circ}$ da $\mathrm{CF}, \mathrm{O}$ Poder Judiciário só admitirá ações relativas à disciplina e às competições desportivas após esgotarem-se as instâncias da justiça desportiva, regulada em lei. Ademais, a Súmula 2 do Superior Tribunal de Justiça colaciona que o habeas data só é cabível se houver recusa de informações pela autoridade administrativa.

\footnotetext{
${ }^{5}$ Art. $2^{\circ} \mathrm{O}$ processo começa por iniciativa da parte e se desenvolve por impulso oficial, salvo as exceções previstas em lei.

${ }^{6}$ Art. 262. O processo civil começa por iniciativa da parte, mas se desenvolve por impulso oficial.

${ }^{7}$ Art. 5- XXXV - a lei não excluirá da apreciação do Poder Judiciário lesão ou ameaça a direito.
} 
Ainda no artigo $3^{\circ}$, é reforçada a ideia de que o estado deve se valer dos equivalentes judiciais, fazendo uso das formas alternativas de resolução de conflitos, ao dispor que o Estado promoverá, sempre que possível, a solução consensual dos conflitos, permitindo assim a arbitragem, a conciliação, a mediação e outros métodos de solução consensual de conflitos deverão ser estimulados por juízes, advogados, defensores públicos e membros do Ministério Público, inclusive no curso do processo judicial. ${ }^{8}$

A mediação configura forma alternativa de resolução de conflitos, que se baseia no exercício da vontade das partes. O diploma em análise, entretanto, não trouxe somente normas principiológicas acerca das formas consensuais de resolução de conflitos, já que destinou uma seção inteira de um capítulo para a sua normatização.

Em relação a arbitragem, esta se verifica quando as partes escolhem um terceiro de sua confiança, que se responsabilizará pela solução do conflito de interesses, sendo que sua decisão se tornará impositiva, resolvendo o conflito independentemente da vontade das partes (NEVES, 2015, p. 61).

Tendo em vista o congestionamento do Judiciário nos dias atuais, permeado, muitas vezes, por demandas que talvez encontrassem melhor resolução na esfera consensual, o Novo CPC, por meio das normas inaugurais principiológicas, e da seção específica, vem dar primazia a essa forma de resolução de conflitos.

\section{PRINCÍPIO DA DURAÇÃO RAZOÁ VEL DO PROCESSO}

Já em seu artigo $4^{\circ}$, o novo CPC codifica o princípio constitucional da duração razoável do processo, ao prever que "as partes têm o direito de obter em prazo razoável a solução integral do mérito, incluída a atividade satisfativa". Este princípio também se encontra positivado no artigo $5^{\circ}$, LXXVIII, que disciplina que a todos, no âmbito judicial e administrativo, são assegurados a razoável duração do processo e os meios que garantam a celeridade de sua tramitação, incluído pela Emenda Constitucional 45/2004, também conhecida como "Reforma do Judiciário", ao reeditar disposição já contida no inciso I do artigo $8^{\circ}$ do Pacto de São José da Costa Rica." ${ }^{\prime 9}$ 
Referido princípio tem por condão, por meio da adoção de técnicas procedimentais no curso do processo, trazer maior celeridade, primando pela eficácia do provimento judicial final, já que a ausência de celeridade acarreta numa forma de ausência de justiça.

O CPC 2015 inova ao trazer a necessidade de observância desse princípio também na fase satisfativa, ou seja, de execução ou cumprimento de sentença, o que se encontrava meramente implícito no texto constitucional. Tal imposição se mostra de ampla validade no contexto processual brasileiro, que, além de imprimir imensa demora na fase de conhecimento da ação, também o faz na fase satisfativa.

Sobre a duração razoável do processo, percebe-se que no Novo CPC, a questão da duração razoável há de ser lida a partir de um referencial mais amplo do que a mera aceleração ou desformalização dos procedimentos. Isso porque a duração razoável dos procedimentos está ligada à celeridade, mas também à solução integral do mérito- e por solução integral o Novo CPC já esclarece que não se está falando apenas da decisão de mérito, mas da efetiva satisfação do direito, ou seja, aqui se fala da primazia do julgamento do mérito que induz o máximo aproveitamento da atividade processual mediante a adoção do aludido novo formalismo democrático ou formalismo conteudístico. (THEODORO JUNIOR, 2015, p.137).

Levam a um processo mais célere as medidas cujo objetivo seja o julgamento conjunto de demandas que gravitam em torno da mesma questão de direito, por dois ângulos: a) o relativo àqueles processos, em si mesmos considerados, que, serão decididos conjuntamente; b) no que concerne à atenuação do excesso de carga de trabalho do Poder Judiciário - já que o tempo usado para decidir aqueles processos poderá ser mais eficazmente aproveitado em todos os outros, em cujo trâmite serão evidentemente menores os ditos “tempos mortos" (= períodos em que nada acontece no processo). (EXPOSIÇÃO... 2010, p. 16).

\footnotetext{
${ }^{8}$ Art. $3^{\circ}$ Não se excluirá da apreciação jurisdicional ameaça ou lesão a direito. $\S 1^{\circ}$ É permitida a arbitragem, na forma da lei. $\S 2^{\circ} \mathrm{O}$ Estado promoverá, sempre que possível, a solução consensual dos conflitos. $\S 3^{\circ}$ A conciliação, a mediação e outros métodos de solução consensual de conflitos deverão ser estimulados por juízes, advogados, defensores públicos e membros do Ministério Público, inclusive no curso do processo judicial.

${ }^{9}$ Artigo $8^{\circ}$ - Garantias judiciais1. Toda pessoa terá o direito de ser ouvida, com as devidas garantias e dentro de um prazo razoável, por um juiz ou Tribunal competente, independente e imparcial, estabelecido anteriormente por lei, na apuração de qualquer acusação penal formulada contra ela, ou na determinação de seus direitos e obrigações de caráter civil, trabalhista, fiscal ou de qualquer outra natureza.
} 
A celeridade, como dever de todos os sujeitos do processo, relaciona-se também com o que prescreve o artigo $5^{\circ}$ do novo diploma processual brasileiro. ${ }^{10} \mathrm{Ou}$ seja, deverá haver boa- fé processual, no sentido de não se interpor recursos desnecessários e protelatórios, prolongando o tempo de proferimento da decisão final, por exemplo.

Como forma de implementação desse princípio, visando a celeridade processual para que se evitem prejuízos decorrentes da demora na resolução da demanda, houve a instituição, no artigo $12^{11}$ da necessidade de observância, por parte dos juízes e tribunais a ordem cronológica de conclusão para proferir sentença ou acórdão.

O CPC Buzaid não instituía uma ordem de julgamento de Processos. Assim, o magistrado poderia estabelecer cronograma de julgamento conforme sua conveniência. $\mathrm{O}$ Novo Código de Processo Civil destitui o julgador dessa faculdade, ao dispor que os processos deverão ser julgados de acordo com a ordem de antiguidade, não se levando em consideração a complexidade da causa.

Deverá, assim, haver a elaboração de uma lista que constará os processos aptos a julgamento, que ficará permanentemente à disposição para consulta pública em cartório e na rede mundial de computadores.

\footnotetext{
${ }^{10}$ Art. $5^{\circ}$ Aquele que de qualquer forma participa do processo deve comportar-se de acordo com a boa-fé.

${ }^{11}$ Art. 12. Os juízes e os tribunais deverão obedecer à ordem cronológica de conclusão para proferir sentença ou acórdão. $\S 1^{\circ} \mathrm{A}$ lista de processos aptos a julgamento deverá estar permanentemente à disposição para consulta pública em cartório e na rede mundial de computadores. $\S 2^{\circ}$ Estão excluídos da regra do caput: I - as sentenças proferidas em audiência, homologatórias de acordo ou de improcedência liminar do pedido; II o julgamento de processos em bloco para aplicação de tese jurídica firmada em julgamento de casos repetitivos; III - o julgamento de recursos repetitivos ou de incidente de resolução de demandas repetitivas; IV - as decisões proferidas com base nos arts. 485 e 932; V - o julgamento de embargos de declaração; VI - o julgamento de agravo interno; VII - as preferências legais e as metas estabelecidas pelo Conselho Nacional de Justiça; VIII - os processos criminais, nos órgãos jurisdicionais que tenham competência penal; IX - a causa que exija urgência no julgamento, assim reconhecida por decisão fundamentada. $\S 3^{\circ}$ Após elaboração de lista própria, respeitar-se-á a ordem cronológica das conclusões entre as preferências legais. $\S 4^{\circ}$ Após a inclusão do processo na lista de que trata o $\S 1^{\circ}$, o requerimento formulado pela parte não altera a ordem cronológica para a decisão, exceto quando implicar a reabertura da instrução ou a conversão do julgamento em diligência. $\S 5^{\circ}$ Decidido o requerimento previsto no $\S 4^{\circ}$, o processo retornará à mesma posição em que anteriormente se encontrava na lista. $\S 6^{\circ}$ Ocupará o primeiro lugar na lista prevista no $\S 1^{\circ}$ ou, conforme o caso, no $\S 3^{\circ}$, o processo que: I - tiver sua sentença ou acórdão anulado, salvo quando houver necessidade de realização de diligência ou de complementação da instrução; II - se enquadrar na hipótese do art. 1.040, inciso II.
} 
Referido artigo traz algumas exceções a essa regra, excluindo dessa ordem cronológica as sentenças proferidas em audiência, homologatórias de acordo ou de improcedência liminar do pedido; o julgamento de processos em bloco para aplicação de tese jurídica firmada em julgamento de casos repetitivos; julgamento de recursos repetitivos ou de incidente de resolução de demandas repetitivas; as decisões proferidas com base nos artigos $485^{12}$ e $932^{13}$; o julgamento de embargos de declaração; o julgamento de agravo interno; as preferências legais e as metas estabelecidas pelo Conselho Nacional de Justiça; os processos criminais, nos órgãos jurisdicionais que tenham competência penal; a causa que exija urgência no julgamento, assim reconhecida por decisão fundamentada. Ademais, após elaboração de lista própria, respeitar-se-á a ordem cronológica das conclusões entre as preferências legais.

\footnotetext{
${ }^{12}$ Art. 485. O juiz não resolverá o mérito quando: I - indeferir a petição inicial; II - o processo ficar parado durante mais de 1 (um) ano por negligência das partes; III - por não promover os atos e as diligências que lhe incumbir, o autor abandonar a causa por mais de 30 (trinta) dias; IV - verificar a ausência de pressupostos de constituição e de desenvolvimento válido e regular do processo; V - reconhecer a existência de perempção, de litispendência ou de coisa julgada; VI - verificar ausência de legitimidade ou de interesse processual; VII acolher a alegação de existência de convenção de arbitragem ou quando o juízo arbitral reconhecer sua competência; VIII - homologar a desistência da ação; IX - em caso de morte da parte, a ação for considerada intransmissível por disposição legal; e X - nos demais casos prescritos neste Código.§ 1 $\underline{\mathrm{O}}$ Nas hipóteses descritas nos incisos II e III, a parte será intimada pessoalmente para suprir a falta no prazo de 5 (cinco) dias.§ $2 \underline{\mathrm{O}}$ No caso do $\S 1 \underline{\mathrm{O}}$, quanto ao inciso II, as partes pagarão proporcionalmente as custas, e, quanto ao inciso III, o autor será condenado ao pagamento das despesas e dos honorários de advogado.§ $3 \underline{\mathrm{O}} \mathrm{O}$ juiz conhecerá de ofício da matéria constante dos incisos IV, V, VI e IX, em qualquer tempo e grau de jurisdição, enquanto não ocorrer o trânsito em julgado.§ $4 \underline{\mathrm{O}}$ Oferecida a contestação, o autor não poderá, sem o consentimento do réu, desistir da ação.§ $5 \underline{\mathrm{O}} \mathrm{A}$ desistência da ação pode ser apresentada até a sentença.§ 6 O Oferecida a contestação, a extinção do processo por abandono da causa pelo autor depende de requerimento do réu.§ $7 \underline{0}$ Interposta a apelação em qualquer dos casos de que tratam os incisos deste artigo, o juiz terá 5 (cinco) dias para retratar-se.

${ }^{13}$ Art. 932. Incumbe ao relator:I - dirigir e ordenar o processo no tribunal, inclusive em relação à produção de prova, bem como, quando for o caso, homologar autocomposição das partes;II - apreciar o pedido de tutela provisória nos recursos e nos processos de competência originária do tribunal;III - não conhecer de recurso inadmissível, prejudicado ou que não tenha impugnado especificamente os fundamentos da decisão recorrida;IV - negar provimento a recurso que for contrário a:a) súmula do Supremo Tribunal Federal, do Superior Tribunal de Justiça ou do próprio tribunal;b) acórdão proferido pelo Supremo Tribunal Federal ou pelo Superior Tribunal de Justiça em julgamento de recursos repetitivos;c) entendimento firmado em incidente de resolução de demandas repetitivas ou de assunção de competência;V - depois de facultada a apresentação de contrarrazões, dar provimento ao recurso se a decisão recorrida for contrária a:a) súmula do Supremo Tribunal Federal, do Superior Tribunal de Justiça ou do próprio tribunal;b) acórdão proferido pelo Supremo Tribunal Federal ou pelo Superior Tribunal de Justiça em julgamento de recursos repetitivos;c) entendimento firmado em incidente de resolução de demandas repetitivas ou de assunção de competência;VI - decidir o incidente de desconsideração da personalidade jurídica, quando este for instaurado originariamente perante o tribunal;VII - determinar a intimação do Ministério Público, quando for o caso;VIII - exercer outras atribuições estabelecidas no regimento interno do tribunal.Parágrafo único. Antes de considerar inadmissível o recurso, o relator concederá o prazo de 5 (cinco) dias ao recorrente para que seja sanado vício ou complementada a documentação exigível.
} 
O julgamento dos feitos em ordem cronológica é decorrência essencial do direito de igualdade, entendido no caso como tratamento isonômico e equitativo. Ora, sabe-se que, por vezes, ações mais complexas são "deixadas de lado" por magistrados assoberbados por grandes volumes de processos, preferindo então, julgar primeiro as mais simples, ainda que a causa mais complexa já esteja pronta para julgamento. Tal prática, no entanto, viola a Constituição (artigo $5^{\circ}$, caput). Por isso, o Novo CPC estabelece não apenas a regra de que os processos devem ser julgados de acordo com a ordem cronológica de conclusão, mas também obriga o Juiz/Tribunal a criar e manter lista de processos aptos para julgamento, trazendo exceções à regra, mas que não desnaturam o fundamento geral (THEODORO JUNIOR, 2015, p.137).

A par da atualidade do tema, a instituição da ordem cronológica de julgamento das demandas, trazida pelo artigo 12 do NCPC já encontra críticas por parte de alguns magistrados.

Para estes, conjugado com o art. 153, segundo o qual "o escrivão ou chefe de secretaria deverá obedecer à ordem cronológica de recebimento para publicação e efetivação dos pronunciamentos judiciais", o novo CPC, se aplicado de maneira intransigente, pode engessar a gestão de processos a ser saudavelmente feita pelo juiz e pelos tribunais, seja no gerenciamento de unidades judiciais (cartórios, secretarias judiciários, servidores, etc.) ou de processos (separação de processos de natureza e complexidade muito diversas, distinção de processo de massa de outros individualizados, etc.). Posta como está, a norma, se trouxer muito mais malefícios do que benefícios, haverá de ser temperada (MENDES DE CASTRO; ÁVILA, online).

\section{A INCLUSÃO DA BOA FÉ OBJETIVA}

Por sua vez, os artigos $5^{\circ}$ e $6^{\circ}$ do Novo CPC dispõem acerca do dever de lealdade processual, ao instituir, respectivamente, que aquele que de qualquer forma participa do processo deve comportar-se de acordo com a boa-fé, e que todos os sujeitos do processo devem cooperar entre si para que se obtenha, em tempo razoável, decisão de mérito justa e efetiva. 
No entanto, o dispositivo traz uma novidade: a inclusão da necessidade expressa de observância do instituto da boa-fé objetiva nas relações processuais. Este dever, apesar de não previsto de forma expressa na Constituição, a própria lógica do sistema determina sua observância. A boa fé objetiva remete à ideia de compreensão ética das relações jurídicas, e tem função de interpretação dos negócios jurídicos em geral, e consiste "em exigir do agente a prática de ato jurídico sempre pautado em condutas normativamente corretas e coerentes, identificados com a ideia de lealdade e lisura. Com isso, confere-se segurança às relações jurídicas, permitindo-se aos respectivos sujeitos confiar nos seus efeitos programados e esperados.” (THEODORO JUNIOR, 2015, p.155).

Ademais, como a segurança jurídica é um dos primeiros fundamentos do Estado Democrático de Direito, é fácil concluir que o princípio da boa fé objetiva não se confina ao direito privado. Ao contrário, expande-se por todo o direito, inclusive o direito público, em todos os seus desdobramentos. Aliás, não é, no plano constitucional, apenas o princípio da segurança jurídica que impõe aos agentes o comportamento segundo a lealdade e a boa-fé. Também a dignidade da pessoa humana o exige, assim como a solidariedade social.

Assim, dentro dos limites do debate processual, a infração ao princípio da boa-fé pode dar origem a inúmeras consequências, tais como a nulidade processual, o dever de indenizar, dentre outros.

Além de importante critério de reprimenda ao abuso de direito processual, a boa-fé processual, como premissa, viabiliza uma chave interpretativa relevante para impedir um formalismo exacerbado, em prol do formalismo processual democrático.

Em síntese, ao expressamente elevar a boa-fé objetiva a princípio processual, o CPC 2015 impõe aos litigantes um comportamento premido pela lealdade processual, que se traduz na obediência a um padrão de conduta que razoavelmente se espera de uma pessoa em uma relação jurídica, impedindo a conduta abusiva e contrária a equidade. 


\section{DEVIDO PROCESSO LEGAL: O CONTRADITÓRIO E A AMPLA DEFESA}

Ninguém será privado de sua liberdade ou de seus bens sem o Devido Processo Legal. Por consequência desse princípio, é assegurado aos litigantes, em processo judicial ou administrativo, e aos acusados em geral o contraditório e a ampla defesa, com os meios e recursos a eles inerentes.

Em virtude do princípio do Contraditório, todas as partes devem ser postas em posição de expor ao juiz suas razões antes que ele profira sua decisão. Ou seja, as partes devem desenvolver suas defesas de maneira plena e sem limitações impostas arbitrariamente. O contraditório pode ser compreendido então, num conceito sintético, como a simétrica paridade de oportunidades de manifestação das partes a cada etapa do processo.

Ou seja, em simétrica paridade, autor e réu devem se manifestar sobre tudo que for trazido aos autos, ajudando e legitimando a decisão judicial. Deverão então exigir do juiz a análise de fatos e fundamentos discutidos previamente no processo. Assim, a garantia do contraditório aparece como elemento legitimador do processo, pois permite que as partes, ao expor suas razões, exerçam suas respectivas influências necessárias na elaboração do provimento judicial. Assim, a simétrica paridade permite assegurar influencia e compensação de eventuais desigualdades entre as partes.

O contraditório se encontra previsto na Constituição Federal de 1988, no artigo $5^{\circ}$, $\mathrm{LV}$, que estabelece que aos litigantes, em processo judicial ou administrativo, e aos acusados em geral são assegurados o contraditório e ampla defesa, com os meios e recursos a ela inerentes, sendo então condição institucional de realização de uma argumentação jurídica consistente e adequada, e com isso, liga-se internamente a fundamentação da decisão jurisdicional participada- exercício de poder participado (THEODORO JUNIOR, 2015, p. $70)$.

Este princípio também indica a atuação de uma garantia fundamental de justiça: absolutamente inseparável da distribuição da justiça organizada, o princípio da audiência bilateral encontra expressão no brocardo romano audiatur et altera par.s Ele é tão intimamente ligado ao exercício do poder, sempre influente sobre a esfera jurídica das 
pessoas, que a doutrina moderna o considera mesmo inerente à própria noção de processo (GRINOVER; CINTRA; DINAMARCO, 2010, p. 86).

O princípio do contraditório se encontra consubstanciado no artigo $7^{\circ}$ do novo diploma processual, sendo assegurada às partes paridade de tratamento em relação ao exercício de direitos e faculdades processuais, aos meios de defesa, aos ônus, aos deveres e à aplicação de sanções processuais, competindo ao juiz zelar pelo efetivo contraditório.

O devido processo legal também encontra-se garantido no artigo $9^{\circ}$, pois este institui que não se proferirá decisão contra uma das partes sem que ela seja previamente ouvida.

O parágrafo único deste artigo traz algumas exceções a esta regra, instituindo que não será aplicado nas hipóteses de tutela provisória de urgência; às hipóteses de tutela da evidência previstas no art. 311, incisos II e III; III, quais sejam, respectivamente, ficar caracterizado o abuso do direito de defesa ou o manifesto propósito protelatório da parte; as alegações de fato puderem ser comprovadas apenas documentalmente e houver tese firmada em julgamento de casos repetitivos ou em súmula vinculante; se tratar de pedido reipersecutório fundado em prova documental adequada do contrato de depósito, caso em que será decretada a ordem de entrega do objeto custodiado, sob cominação de multa; e à decisão prevista no art. 701.

Sendo evidente o direito do autor, o juiz deferirá a expedição de mandado de pagamento, de entrega de coisa ou para execução de obrigação de fazer ou de não fazer, concedendo ao réu prazo de 15 (quinze) dias para o cumprimento e o pagamento de honorários advocatícios de cinco por cento do valor atribuído à causa).

O Novo CPC, desde a sua redação original, deixou evidente uma maior preocupação normativa em levar o princípio do contraditório a outro nível de compreensão, passando a ser entendido como direito de participação na construção do provimento, sob a forma de uma garantia processual de influência e não surpresa para a formação das decisões (THEODORO JUNIOR, 2015, p. 69).

A forma pela qual o Contraditório foi introduzido no novo CPC, dentro de uma visão constitucional, permitirá, ao mesmo tempo, a busca dentro dos limites legais, do 
desenvolvimento do processo num tempo razoável, e um debate processual que implica na formação do pronunciamento judicial seguindo-se os ditames democráticos.

O CPC 2015, com isso em mente, se pauta pela ideia de cooperação/comparticipação entre juiz, partes e seus advogados, tendo em vista o papel fundamental destes últimos no desenvolvimento válido e regular do processo, que, se efetivamente concretizada, pode conduzir a uma nova forma de implementação da cognição, ao se perceber que um debate bem feito conduz à redução do tempo processual e à diminuição da utilização de recursos, em virtude do proferimento de decisões mais bem construídas (THEODORO JUNIOR, 2015, p. $71)$.

Nessa renovada análise do sistema processual, o princípio constitucional do contraditório ganha nítido destaque ao garantir uma busca de simetria de posições subjetivas, além de assegurar aos participantes do processo a possibilidade de dialogar e de exercitar um conjunto de controles, de reações e de escolhas dentro dessa estrutura.

Da conceituação do princípio do contraditório, trazida pelo Novo Código, percebe-se que este não se resume a uma mera garantia formal de bilateralidade da audiência, mas sim uma possibilidade efetiva de influência sobre o desenvolvimento do processo e sobre a formação das decisões racionais, com reduzidas ou inexistentes possibilidades de surpresa (THEODORO JUNIOR, 2015, p. 76).

Ou seja, não se pode mais compreender que o contraditório se limite ao dizer e contradizer formal entre as partes, sem que isso gere uma efetiva contribuição para a fundamentação do provimento, ou seja, afastando a ideia de que a participação das partes no processo possa ser meramente ficta, garantindo-se a possibilidade de participação preventiva sob qualquer aspecto fático ou jurídico que esteja sendo discutido ou julgado.

A garantia opera não somente no confronto entre as partes, transformando-se também num dever para o juiz, que passa a ter de provocar de ofício o prévio debate das partes sobre quaisquer questões de fato ou de direito relevantes para a resolução da demanda (THEODORO JUNIOR, 2015, p. 77).

Impõe-se ao julgador também o dever de informar às partes as iniciativas que pretende exercer, de modo a permitir a elas um espaço de discussão em contraditório, devendo 
haver a institucionalização e expansão do dever de esclarecimento judicial a cada etapa do procedimento, inviabilizando um julgamento surpresa (THEODORO JUNIOR, 2015, p. 79).

Desse modo, o contraditório, na forma trazida pelo Novo CPC, constitui uma verdadeira garantia de não surpresa que impõe ao juiz o dever de provocar o debate acerca de todas as questões, mesmo aquelas de ordem pública, sendo nula a decisão que contrarie essa premissa.

\section{A PUBLICIDADE PROCESSUAL E A NECESSIDADE DE MOTIVAÇÃO DAS DECISÕES}

O artigo 11 do Código de Processo Civil de 2015 disciplina a regra constitucional de publicidade doas atos processuais, ao instituir que todos os julgamentos dos órgãos do Poder Judiciário serão públicos, e fundamentadas todas as decisões, sob pena de nulidade. A exceção a essa regra se dá nos casos de segredo de justiça, em que pode ser autorizada a presença somente das partes, de seus advogados, de defensores públicos ou do Ministério Público.

Referida norma já vinha positivada no texto constitucional, em seu artigo $5^{\circ}$, LX, que a lei só poderá restringir a publicidade dos atos processuais quando a defesa da intimidade ou o interesse social o exigirem. A codificação desse preceito no diploma processual civil só confirma a efetiva constitucionalização do processo civil. Ou seja, não há como se dissociar a Constituição, vetor do ordenamento jurídico brasileiro do sistema processual, pois ambos se complementam.

Principio inerente a atividade jurisdicional, a publicidade garante ao indivíduo o acompanhamento nos atos públicos que constituem o exercício da jurisdição. Entretanto, a publicidade processual pode ser restrita nos casos em que a preservação do direito à intimidade do interessado no sigilo não prejudique o interesse público à informação.

Ademais, prestigiando o princípio constitucional da publicidade das decisões, previuse a regra inafastável de que à data de julgamento de todo recurso deve-se dar publicidade (todos os recursos devem constar em pauta), para que as partes tenham oportunidade de tomar 
providências que entendam necessárias ou, pura e simplesmente, possam assistir ao julgamento (EXPOSIÇÃO... 2010, p. 16).

\section{O ARTIGO $8^{\circ}$ DO NCPC E A APLICAÇÃO TELEOLÓGICA DO ORDENAMENTO JURÍDICO}

O artigo $8^{\circ}$ do Novo Código de Processo Civil inova no ordenamento processual, ao dispor que ao aplicar o ordenamento jurídico, o juiz atenderá aos fins sociais e às exigências do bem comum, resguardando e promovendo a dignidade da pessoa humana e observando a proporcionalidade, a razoabilidade, a legalidade, a publicidade e a eficiência.

Percebe-se, pela redação do dispositivo legal, que este fez alusão à regra contida no artigo $5^{\circ}$ da Lei de Introdução às Normas ao do Direito Brasileiro, o qual colaciona que na aplicação da lei, o juiz atenderá aos fins sociais a que ela se dirige e às exigências do bem comum.

Assim, o dispositivo processual prima pela aplicação teleológica da norma, ou seja, a norma deve ser aplicada e interpretada de forma a levar em consideração os fins sociais a que esta se dirige, com o objetivo de buscar-se a pacificação social.

Mais uma vez, percebe-se a influência do sistema constitucional de proteção à dignidade da pessoa humana presente no texto do Código, que induz o juiz a sempre buscar o bem comum, de forma a proteger o indivíduo e evitar arbítrios estatais.

Em outra inovação legislativa, foram incluídos os princípios da razoabilidade e da proporcionalidade, além daqueles que guiam a Administração Pública em suas funções estatais.

\section{ANÁLISE DO CAPÍTULO II: APLICAÇÃO DAS NORMAS PROCESSUAIS}

O Capítulo II do Livro I do Novo CPC trata acerca aplicação da norma processual no tempo e no espaço. Iniciando a sessão, o artigo 13 disciplina que a jurisdição civil será regida 
pelas normas processuais brasileiras, ressalvadas as disposições específicas previstas em tratados, convenções ou acordos internacionais de que o Brasil seja parte.

No tocante ao tratamento ofertado a norma de caráter internacional, este artigo parece ter adotado a teoria monista, que defende a primazia do direito internacional sobre o interno. Isso porque, ao utilizar a expressão "ressalvadas", o legislador, ao menos num primeiro momento, determina que a norma brasileira somente deve ser utilizada se não houver disposições internacionais que regulem o tema.

A norma em questão parece tentar se alinhar com aquilo disposto no artigo $5^{\circ}$, parágrafo $2^{\circ}$ da Constituição Federal ${ }^{14}$. No entanto, não o faz de maneira correta, pois a norma constitucional não impõe exclusão da norma interna quando esta se confrontar com uma norma internacional, mas sim apresenta relação de complementariedade entre essas duas normas.

Sabe-se que os tratados que versam sobre direitos humanos, e que forem internalizados pelo rito previsto no paragrafo $3^{\circ}$ do artigo $5^{\circ}$ da Constituição federal terão status de emenda constitucional. Em virtude disso, nenhuma outra norma poderá lhe ser contrária, já que a Constituição é vetor máximo do sistema jurídico brasileiro, devendo todas as normas de hierarquia inferiores com ela ser compatíveis.

Há também aqueles tratados internacionais que, tratado acerca de direitos humanos, ao não serem internalizados segundo o rito do paragrafo terceiro do artigo $5^{\circ}$, detém status de norma supralegal, se localizando acima das leis ordinárias e abaixo da Constituição na pirâmide normativa. As leis ordinárias deverão se submeter ao controle de convencionalidade, ou seja, não deverão contrariar o disposto nos tratados que versem sobre direitos humanos, mas não detém status de emenda constitucional.

\footnotetext{
${ }^{14}$ Os direitos e garantias expressos nesta Constituição não excluem outros decorrentes do regime e dos princípios por ela adotados, ou dos tratados internacionais em que a República Federativa do Brasil seja parte.
} 
Assim, se um tratado internacional eventualmente vier a regular o devido processo legal, este, pelo fato desse princípio ser considerado uma garantia fundamental, terá status ou de emenda constitucional, ou de norma supralegal, a depender do processo de internalização, e apresentará hierarquia formal sobre o novo CPC, segundo o disposto no artigo 12 do referido diploma legal.

$\mathrm{O}$ artigo 14 trata da aplicabilidade da norma processual no tempo, ao instituir que a norma processual não retroagirá e será aplicável imediatamente aos processos em curso, respeitados os atos processuais praticados e as situações jurídicas consolidadas sob a vigência da norma revogada.

Referido dispositivo normativo introduz expressamente no ordenamento processual civil norma já existente na Lei de Introdução às Normas de Direito Brasileiro, prevista em seu artigo $6^{\circ} .{ }^{15}$ Assim, a lei em vigor terá efeito imediato e geral, respeitados o ato jurídico perfeito, o direito adquirido e a coisa julgada. Somente por expressa disposição de lei é possível a retroatividade.

Encerrando o capítulo II do Livro I, o artigo 15 disciplina sobre a aplicação subsidiária e supletiva do NCPC, nos casos de ausência de normas que regulem processos eleitorais, trabalhistas ou administrativos. ${ }^{16}$

\footnotetext{
${ }^{15}$ Art. $6^{\circ}$ A Lei em vigor terá efeito imediato e geral, respeitados o ato jurídico perfeito, o direito adquirido e a coisa julgada. $\S 1^{\circ}$ Reputa-se ato jurídico perfeito o já consumado segundo a lei vigente ao tempo em que se efetuou.

$\S 2^{\circ}$ Consideram-se adquiridos assim os direitos que o seu titular, ou alguém por ele, possa exercer, como aqueles cujo começo do exercício tenha termo pré-fixo, ou condição pré-estabelecida inalterável, a arbítrio de outrem. $\S 3^{\circ}$ Chama-se coisa julgada ou caso julgado a decisão judicial de que já não caiba recurso.

${ }^{16}$ Art. 15. Na ausência de normas que regulem processos eleitorais, trabalhistas ou administrativos, as disposições deste Código lhes serão aplicadas supletiva e subsidiariamente.
} 


\section{CONCLUSÃO}

Ao longo do presente artigo procurou-se analisar, pontualmente, as alterações trazidas na legislação processual civil inclusão do Livro I do Novo Código de Processo Civil.

Conclui-se, então, a partir desse estudo, que a nova codificação veio para confirmar e enaltecer o fenômeno da constitucionalização do processo civil. Com a inclusão de princípios que anteriormente decorriam somente do sistema constitucional, já que não estavam contidos no código anterior de forma expressa, percebe-se que o processo encontra-se constitucionalizado.

Isso porque, definitivamente, superou-se o Estado Legalista e impôs-se o Estado Constitucional. O homem de mero coadjuvante passa a ser ator principal traduzido em sua dignidade, e institutos clássicos do processo civil são redimensionados sob a ótica dos direitos fundamentais. Ao Estado não cabe mais o papel burocrático de garantir ao cidadão uma sentença inerte e ineficaz, cabe-lhe agora promover a proteção apropriadamente concreta sob a nomenclatura de tutela jurisdicional efetiva adequada e adaptável ao direito material.

A tutela jurisdicional deve ser prestada de forma a velar pelos princípios constitucionais que, com a promulgação do NCPC, passaram a ter previsão na legislação processual civil. As leis processuais comuns formam um arcabouço instrumental destinado, sobretudo, a disciplinar os aspectos procedimentais para se alcançar a tutela jurisdicional. De modo algum, sua interpretação e manejo podem contrariar as regras e princípios traçados pela ordem constitucional (onde hoje se insere a essência do tratamento jurídico-institucional do processo e da jurisdição).

\section{REFERÊNCIAS}

ABREU, Pedro Manoel. Novo Processo Civil Imantado pelo Constitucionalismo Contemporâneo. In: Revista SJRJ, V. 18, n. 31. Rio de Janeiro, ago. 2011.

ACOSTA, Hermógenes. Proceso Civil y Constitución. In:ACOSTA, Hermógenes; PLAZAS, Jose Machado; SUZAÑA, Manuel Ramírez; PICÓ I JUNOY, Joan (coords.). 
Constitucionalización del Proceso Civil. 1ª Ed.. Santo Domingo: Escuela Nacional de la Judicatura, 2005.

AROCA, Juan Montero. Los Principios Informadores del Proceso Civil en el Marco de La Constitución. In: Revista Justicia 82, n.o IV.

BEDAQUE, José Roberto dos Santos. Direito e processo - influência do direito material sobre o processo. 5. ed. São Paulo: Malheiros Editores, 2009.

BARROSO, Luís Roberto. Neoconstitucionalismo e constitucionalização do Direito. O triunfo tardio do Direito Constitucional no Brasil. THEMIS: Revista da ESMEC / Escola Superior da Magistratura do Estado do Ceará. Fortaleza, v. 4, n. 2, p. 18-19, jul/dez. 2006.

CÂMARA, Alexandre Freitas. Lições de direito processual civil.16 ed. Rio de Janeiro: Lumen Juris, 2008.

CATTONI, Marcelo. Direito processual constitucional. Belo Horizonte: Mandamentos, 2001.

COSTA, Miguel do Nascimento. Poderes do Juiz, Processo Civil e suas Relações com o Direito Material. Volume 2. Coleção Estudos de Direito em Homenagem ao Prof. Darci Guimaraes Ribeiro. Porto Alegre: Verbo Jurídico, 2013.

CRUZ, Danilo Nascimento. Premissas históricas e teóricas sobre a constitucionalização do direito. Revista da Escola da Magistratura Regional Federal da $2^{\mathrm{a}}$ Região - EMARF. Rio de Janeiro: EMARF - TRF 2a Região / RJ 2010 - volume 13, n. 1, p. 205-224, mai. 2010.

CRUZ, DANILO NASCIMENTO, PIAULINO, Karine Rodrigues. Processo Civil Contemporaneo: Aspectos Conceituais; constitucionalização e tutela jurisdicional efetiva. Revista Escola da Magistratura Regional Federal da 2a Região. Volume 14- Novembro de 2010. p. 209.

DIDIER, Fredie. Curso de direito processual civil - vol.3. 3. ed. Bahia: Jus Podivm, 2014. DINAMARCO, Cândido R.. Instrumentalidade do Processo. $14^{a}$ Ed.. São Paulo: Malheiro Editores, 2009.

Exposição de Motivos do Projeto do Novo Código Civil. Disponível em: 
<http://www2.camara.leg.br/atividade-legislativa/comissoes/comissoestemporarias/especiais/54a-legislatura/8046-10-codigo-de-processo-civil/arquivos/quadrocomparativo-do-cpc-atual-e-pl-8.046-11>. Acesso em: 28 de julho de 2015 p. 14.

GRINOVER, Ada Pellegrini; CINTRA, Antônio Carlos de Araújo; DINAMARCO, Cândido Rangel. Teoria Geral do Processo. 24 ${ }^{\mathrm{a}}$. ed. São Paulo: Malheiros Editores, 2010, p.84.

GUASTINI, Riccardo. La Constitucionalización del Ordenamiento Jurídico: el Caso Italiano.In: CARBONELL, Miguel. Neoconstitucionalismo (s). Madrid: Editorial Trotta, 2003.

MARINONI. Luiz Guilherme. A jurisdição no estado constitucional. Disponível em: <http://www.professormarinoni.com.br>. Acesso em: 22 de julho de 2015.

Da teoria da relação jurídica processual ao processo civil do estado constitucional. Disponível em: <http://www.professormarinoni.com.br>. Acesso em: 22 de julho de 2015.

MENDES DE CASTRO, Aluisio, ÁVILA, Hemrique. Algumas das principais alterações do novo Código de Processo Civil. Dísponível em <http://www.conjur.com.br/2015-jan31/algumas-principais-alteracoes-codigo-processo-civil>. Acesso em 28 de julho de 2015.

MÉNDEZ, Francisco Ramos. La Influencia de la Constitución en el Derecho Procesal Civil. In: Revista Justicia 83, n.o 1.

NERY JUNIOR, Nelson; NERY, Rosa Maria de Andrade. Código de processo civil comentado. 12. ed. São Paulo: RT, 2012.

NERY JUNIOR, Nelson. Princípios do processo civil na Constituição Federal. 10. ed. São Paulo: Revista dos Tribunais, 2010.

NEVES, Daniel Amorim Assumpção. Manual de direito processual civil. São Paulo: Método. 2015. p. 61.

THEODORO JUNIOR, Humberto. Curso de direito processual civil. Vol. 1. 55 ed. Rio de Janeiro: Forense, 2014. 
Direito Processual Constitucional. Estação Científica (Ed. Especial

Direito) Juiz de Fora, V.01, n.04, outubro e novembro/2009 .

THEODORO JUNIOR, Humberto. Novo CPC: fundamentos e sistematização. Rio de Janeiro: Forense, 2015.

WATANABE, Kazuo. Da cognição no processo civil. 4 ed. São Paulo: Saraiva, 2012. ZANETI JUNIOR, Hermes. A Constitucionalização do Processo: A Virada do Paradigma Racional e Político no Processo Civil Brasileiro do Estado Democrático Constitucional. Porto Alegre, 2005, f.251-252. Tese (Doutorado em Direito) - Universidade Federal do Rio Grande do Sul, Rio Grande do Sul, 2005. 